\title{
Writing/righting a history of Australian Aboriginal art
}

\section{Susan Lowish}

The writing of Aboriginal history has never been free of political implications...literature reveals and reinforces the changing hues of dominant social and political ideas, especially relating to race and colonialism.

- Ann McGrath and Andrew Markus ${ }^{1}$

More sophisticated equivalences are starting to be made between works of Aboriginal art and the rest of the objects that inhabit the art world; ${ }^{2}$ as such, this is an exciting time for the discipline of art history. It is also a dangerous time, as it negotiates pathways through different narratives and is confronted with the dynamic interface of Indigenous and settler art histories. This paper discusses some of the problematic methodological approaches adopted by art historians and anthropologists in several major publications that have become standards in the fields of Australian and Aboriginal art. It examines the use of the label 'Aboriginal art' as an identifier of a category the contents and borders of which are currently racially defined and argues that a temporal emphasis be adopted that would see 'Aboriginal art' understood more as a period style. It argues that different kinds of primitivism have contributed to and maintained the difficulties in relating Aboriginal art to Australian art and vice versa. Finally, this paper considers how Aboriginal art can be written about in the future and asks how best to proceed. How do we write (or right) the history of Australian Aboriginal art?

For a long time now, there have been requests for more critical engagement with the art of Indigenous Australians. These requests have come from artists keen for dialogue and from scholars seeking to analyse the critical reception of the work. More than 15 years ago, the need for critical theory was clearly outlined by noted scholar and Indigenous rights advocate Marcia Langton in relation to Indigenous film and video production. ${ }^{3}$ She argued that new critical frameworks were needed for analysing the representation of Indigenous peoples because discourse too often revolved around questions of authenticity. In 2000, art historian Roger Benjamin reviewed some of the difficulties in writing critically about the artwork of Indigenous Australians - especially by settler Australians and other people of non-Indigenous descent. He cited the political situation in Australia and the Eurocentric basis of critical concepts as being among the major obstacles to writing about this art. ${ }^{4}$ 
Notably, Benjamin has recently curated an exhibition in the United States of early works from Papunya. Journalist Nicolas Rothwell goes so far as to declare that Benjamin's work opens up 'a new chapter in Aboriginal art criticism'. ${ }^{5}$ His catalogue text supposedly 'liberate[s] the viewer from the perspective of anthropology and encourage[s] a new mode of looking at Papunya work' ${ }^{6}$ While Benjamin does bring his own inimitable style to the writing, it surely benefits from the incorporation of work by noted anthropologists such as Nancy Munn and Fred Myers, whose rigorous fieldwork and grasp of Indigenous languages and concepts are used to augment Benjamin's own visual analysis.

While the exhibition will not travel to Australia due, we are told, to Indigenous opposition to the revelation of sacred imagery, the emphasis on beauty, multiplicity of interpretations and, in short, the qualities that characterise 'great art' in the high modernist sense are emphasised in the collection and curatorship of this exhibition and some of the writing in the catalogue. One is left wondering whether keeping the exhibition overseas also enables avoidance of certain 'obstacles': engaging politically with Indigenous Australians over the ownership, display and publication of some very valuable cultural material within Australia's colonial context.

Of course, part of the difficulty for all art critics has been determining the criteria for making aesthetic judgements in relation to an art that appears to have come from a completely different aesthetic tradition, employing largely unfamiliar iconography and requiring entirely different bases for analysis. Some, like Eric Michaels, have argued that Aboriginal art is 'the product of too many discourses' and that 'contradictions of this system [of production and circulation] resist resolution'. ${ }^{7}$ For others, like Howard Morphy, it is possible and necessary to find cross-cultural equivalences in the understanding of art. ${ }^{8}$ Although I believe that through an analysis of art over time it is possible to chart the ways in which Indigenous art for sale has responded to the shifting tastes of the market, the ways in which this discourse plays itself out on the printed page are not straightforward and present a dilemma that still besets attempts at critical writing on Aboriginal art.

Similar to criticism, the writing of histories of Indigenous art in Australia is also an area fraught with difficulty. ${ }^{9}$ Langton argues that the history of filmic productions of Indigenous Australians is deeply racist, distorted and often offensive. ${ }^{10}$ Indeed, it has only been since the 1970s, with the pioneering work of Essie Coffey - who directed My Survival as an Aboriginal (1979) - and the intense negotiation captured by Ian Dunlop at the beginning of the Yirrkala Film Project (ca 1970), recently highlighted by Pip Deveson, ${ }^{11}$ that Indigenous people have been seen to be actively involved in making film and video. This aspect of the history of Indigenous film is analogous to writing on art, as it has 
only been in the very recent past that accounts of Indigenous art production have actively involved Indigenous voices.

Although it is just as racist to believe that Indigenous Australians will make 'better' representations simply by being 'Aboriginal', 12 Indigenous perspectives are the most vital part of what has been a field dominated largely by non-Indigenous people. Langton identifies the central problem as

the need to develop a body of knowledge on representation of Aboriginal people and their concerns in art, film, television and other media and a critical perspective to do with aesthetics and politics, drawing from Aboriginal world views, from Western traditions and from history. ${ }^{13}$

Langton advocates placing Indigenous and non-Indigenous views together into dialogue. If done well, the results can be spectacular.

While there is an almost overwhelming amount of material already published on Indigenous Australians, much of the older material sits firmly within the Western traditions of archaeology, anthropology and ethnology. Very little seems to incorporate Indigenous world views in an active sense (as opposed to their being passive subjects of the research) or makes much of an effort to contextualise these views historically. In relation to Aboriginal art, some publications that go towards redressing this imbalance are: Yarrtji: Six women's stories from the Great Sandy Desert (1997) by Tjama Freda Napanangka et al.; Saltwater: Yirrkala bark paintings of sea country. Recognising indigenous sea rights (1999) by the team at Buku-Larrnggay Mulka; Gwion Gwion: Secret and sacred pathways of the Ngarinyin Aboriginal people of Australia (2000), authored by four Ngarinyin elders and men of law, Ngarjno, Ungudman, Banggal and Nyawarra; and, most recently, Aboriginal Art: Creativity and assimilation (2008) by Gamilaroi artist and art historian Donna Leslie. There are also a number of monographs on and by artists working in a wide range of styles and media, including Yirawala, Fiona Foley, Ginger Riley and Kathleen Petyarre.

In What is Art History? (1976), Mark Roskill describes the monograph as 'the most basic type of publication that art historians produce'. ${ }^{14}$ That there are relatively few monographs on Indigenous artists, and even fewer by self-declared art historians, highlights the lack of resources and scholarship of an art-historical nature for Aboriginal art. Ideally, the catalogue raisonné should be the honest estimate of an artist's art-historical stature:

The catalogue raisonné is just that - reasoned - and serves three purposes: the establishment by critical means of an artistic oeuvre; enabling others to find what you could not; providing, through selection and discussion, elements likely to be of use to others working in the same general area and more than likely facing much the same problems. ${ }^{15}$ 
There is yet to be a catalogue raisonné of the artistic output of any Indigenous Australian artist. At best, this situation suggests a lack of resources; at worst, it suggests that art historians have been slow to accept the idea of individual Indigenous artists or have not considered Aboriginal art to be an appropriate area of study. The concept of the artist is culturally constructed. ${ }^{16}$ Clearly, the concept of Indigenous artist is constructed differently and has a distinctly different historical trajectory to the concept of non-Indigenous artist. ${ }^{17}$ Until the fundamentals are in place, the art history of Aboriginal art will remain an impoverished field.

There are a number of recently published works that attempt a more comprehensive overview of the history of movements or styles in Indigenous art. $^{18}$ None of these works, however, could be strictly considered a history of Aboriginal art. Owing to the great diversity in artists, artworks, themes and ideas, the need to construct working methodologies for rigorous criticism and the sheer amount of knowledge required to come close to mapping related historical processes, authoring the definitive volume is probably an impossible task. Aboriginal Art (1998) by anthropologist Howard Morphy outlines episodes in the history of the production, circulation and reception of a number of works, styles and mediums in a roughly chronological order. Morphy's work stands out because it is alive to the complexity of discourses surrounding Indigenous art works. He maintains an emphasis on how knowledge is generated about Indigenous Australians throughout his discussion.

Morphy writes:

[T] he recent history of Aboriginal art has been a dialogue with colonial history, in which what came before - an Aboriginal history of Australia with its emphasis on affective social and spiritual relationships to the land - is continually asserting itself over what exists in the present. ${ }^{19}$

Morphy presents the history of Indigenous art as a dynamic exchange. More recently, the notion of dialogue has found some currency among established art historians. Sasha Grishin, who heads the Art History Department at The Australian National University, has recently authored an article titled 'A new history of Australian art: dialectic between Indigenous and non-Indigenous art $^{\prime}{ }^{20}$ The article outlines the methodology for a forthcoming book:

The methodological contention in this study is that non-Indigenous art in Australia has always been to some extent involved in a dialectic with Indigenous art and that this together with the multicultural composition of the population as well as the country's proximity to Asia, have all contributed to a visual culture which is unique and distinctive. ${ }^{21}$

This refiguring of the importance of the relationship between Indigenous and non-Indigenous art could put Grishin in direct opposition to the 'father of 
Australian art history', Emeritus Professor Bernard Smith, who, in 2005, wrote of the inclusion of Aboriginal art: 'it does falsify the history of taste in Australia to insert art works into periods when they would have never been thought of as art in the special sense. ${ }^{22}$ It is, however, best left to Grishin to defend his thesis when the book is out. Far more interesting for the present debate is Morphy's proposed shift in the way in which the very terms of the relationship between Indigenous and non-Indigenous art are conceived.

In the final paragraphs of Aboriginal Art (1998), Morphy comes to the conclusion that if the hierarchy present in extant art histories was reversed 'the boundaries between Aboriginal and non-Aboriginal art history would be dissolved, but in such a way that world art history would be rewritten in relation to present Aboriginal art practice' ${ }^{23}$ This deconstructionist manoeuvre works well to expose the hegemony of Eurocentric notions of history - a hegemony so complete that it is only through such a radical reversal that the power relations that exist within current art-historical attitudes to Indigenous art become apparent. Imagine the uproar if one were to write the history of Australian Aboriginal art, briefly mentioning 'Western art' as an undifferentiated, de-historicised whole and then enforcing this as the only true narrative: the real story. It is only once we accept the outrageousness of the situation in reverse that we can begin to understand the present and also the need for the re-evaluation of European encounters with Aboriginal art. As Langton tells us, Indigenous perspectives are needed to redress this imbalance.

\section{Aboriginal art in Australian art histories}

More often than not, Australia's Indigenous art is described as the oldest surviving art tradition in the world, yet categorising the history of its production as art history has been attempted only recently. In 2001, senior curator and historian Andrew Sayers published a revised Australian art history as part of the Oxford History of Art series, in which he wrote: 'Aboriginal art does have an art history, in the accepted meaning of that term.' ${ }^{\prime 24}$ In his introduction, Sayers succinctly outlines his strategy of including many Indigenous works in his discussion of Australian art: 'the shared destiny of peoples in Australia must be reflected in the history of its art. ${ }^{25}$ Aware of the political, historical and cultural meaning of the adjective 'Australian' and that including Aboriginal art within the history of Australian art might be seen as 'cultural appropriation', Sayers seeks to negotiate this problematic term by maintaining that there is 'a duality in the art of Australia'. ${ }^{26}$ This duality exists because 'Aboriginal art is fundamentally different in conception from the art of Europeans in Australia' ${ }^{27}$ There is, according to Sayers, a "'basic ontological gap" between Aboriginal and non-Aboriginal views' ${ }^{28}$ 
Whereas Morphy sees Indigenous art as a dialogue with colonial history, Sayers favours a comparative approach, as illustrated by his analysis of two images of Groote Eylandt: one by William Westall and the other by Gulpidja. ${ }^{29}$ The images are juxtaposed, with little information provided about the works. Lacking any real discussion about Indigenous aesthetic conventions, an equivalence is assumed and judgments of taste ensue. One of the dangers with this approach is that analysis leads to reinforcement of the same/other distinction rather than any form of rapprochement. Langton implores us to reduce the visual cultural disparity through informed critique; Sayers argues that Indigenous art remains distinct from the rest of Australian art at its conception. He describes his newly shaped history of Australian art as being more of a 'journey through a landscape with stops along the way' than a search for a connecting idea that will traverse all Australian art. ${ }^{30}$

Although his position has since developed, as seen in the National Portrait Gallery's opening temporary exhibit, Open Air: Portraits in the landscape, which extends the notion of portraiture to include various forms of Indigenous art, Sayers' 2001 version of Australian art history reveals a fairly singular perspective. His history is inclusive of Indigenous art at least on one level, insisting that it can only be a distortion to see Aboriginal art as wholly separate from some other field which might be designated as "Australian art"". 31 The ultimate impression, however, is one of insurmountable difference: we know this art exists, we must therefore try to incorporate it into our history, but it appears to be so different that only the most tenuous links to settler Australian art can be made. Sayers' work is an example of an attempt to acknowledge Aboriginal art in the history of Australian art but without trying to understand it. His history does not translate as 'cultural appropriation', which is what he fears; rather, the engagement with the works is superficial and relies primarily on their visual impact, doing little to disrupt the status quo.

Art critic and lecturer Christopher Allen presents a starkly different approach to the history of Australian art, despite using many of the same art works as Sayers to illustrate his narrative. In the 224 pages of Art in Australia: From colonisation to postmodernism (1997), he mentions Aboriginal art twice. The first instance is in relation to the Australian painter Margaret Preston, for whom 'Aboriginal art offered the possibility of a reconciliation between modernism and the nationalist landscape tradition'. ${ }^{32}$ The second instance can be found in the final paragraphs, where Allen writes of the present popularity of desert acrylic painting in Australia and internationally. He describes this 'trend' as a new authenticity seized by a desperate art world. ${ }^{33}$ There is no attempt to engage with any Aboriginal artworks and no individual Indigenous artists are mentioned by name. 
Langton states that 'the barely concealed suspicion of the most acerbic critics of the Aboriginal art market is that transactions are driven by a demand for a primitivist art product as surrogate contrition'. ${ }^{34}$ She might well be referring to Allen, as he argues that acrylic painting represents 'the latest avatar of the Aborigine in European Australian culture'. ${ }^{35}$ Allen is openly antagonistic towards any revision of the importance of 'Aboriginal art' in Australian art history, closing his commentary with the contentious statement: 'Aboriginal art has had, practically speaking, no effect on contemporary Australian art.' ${ }^{36}$ This is in direct contrast with Sayers' view that 'demarcations in the forms of indigenous art and non-indigenous art are breaking down' ${ }^{37}$ it also flies in the face of figuring Australian art history as a dialogue, as proposed first by Morphy and now Grishin.

Allen's and Sayers' publications are just two examples of histories of Australian art. They can, however, be seen as indicative of two main approaches to the positioning of Aboriginal and Australian art histories: Sayers being 'inclusionist' and Allen exclusionist. We can see this in operation at the level of narrative. Whereas Sayers argues that the relationship of people to the land has been an enduring theme in Australian culture and his history of art is built around this important idea, ${ }^{38}$ for Allen, the failure of settler Australians to connect with the land is the defining characteristic. For this reason, and because the publishers, Thames and Hudson, devoted another book in their World of Art series to Aboriginal art (Caruana 1993, revised 2003), Allen restricts the content of Art in Australia to art made by non-Indigenous people. While this provides a neat framing narrative for a particular Australian art history, it enforces a view of 'Aboriginal art' as having outsider status.

There have been other major publications in the field of Australian art history, including John McDonald's Art of Australia. Volume 1: Exploration to Federation (2008), discussed below, and The New McCulloch's Encyclopedia of Australian Art by Alan McCulloch, Susan McCulloch and Emily McCulloch Childs (2006). The most disturbing aspect of The New McCulloch's is its separate section on Aboriginal art. Why Indigenous artists are sectioned off like this is not made exactly clear. When Susan McCulloch was asked about it in an interview, she replied:

It's really for the convenience of the reader. It's not intended to be a separationist thing. It's just that, when you're reading — we have several sections that are divided into their own areas, such as exhibitions, galleries and prizes, and we felt that Aboriginal art was so much a contained flow of its own dynamic, interwoven with the rest of Australian art-there are crosses over in the rest of the text as well, but, from a purely practical point of view, we felt that it was much easier for people to look up a Tjupurrula or a Japanangka or a Napanangka in their own 
section, because you almost need to know what you're looking for before you can find it, if it's not in its own section. ${ }^{39}$

Of course, it is also easier to keep treating Aboriginal art as a 'special case' by placing the issues raised by its appreciation in the too-hard basket. Isn't it about time we all learn artists' names and get used to saying them? If it is confusing to have too many Tjakamarras, then what about all the Smiths, Boyds and Lindsays?

Apparently, there were months of discussion in the McCulloch camp about the decision to section off 'Aboriginal art and artists' and most of their supporters from the rest of 'Australian art and artists' in this encyclopedia. Albert Namatjira and Yirawala, Leonhard Adam and Baldwin Spencer were integrated in Alan McCulloch's 1984 edition, but sectioned off in 2006. Curiously, Rex Battarbee remains with the rest of the 'whiteys', although his main claim to fame is not his artwork but that he briefly taught, and more notably promoted, Namatjira. There are many other artists who perhaps more properly belong in the main body of the text - not because they are so well known, such as Rover Thomas, Emily Kngwarreye or Clifford Possum, but because they actively oppose being labelled as 'Aboriginal artists'. Tracey Moffatt, Gordon Bennett and Brook Andrew are just some of the most prominent proponents of this particular point of view.

To assert that the history of Australian art has been written largely at the exclusion of Indigenous art and artists is to make no great claim. This does not, however, negate the need for investigating and exposing the reasons for this exclusion. Olu Oguibe, who writes on contemporary African art, suggests one reason:

It is evidence of the arrogance of occidental culture and discourse that even the concept of history should be turned into a colony whose borders, validities, structures and configurations, even life tenure are solely and entirely decided by the West. This way history is constructed as a validating privilege which it is the West's to grant. ${ }^{40}$

Oguibe's stance can be read as a reaction against centuries of ignorance and paternalistic attitudes displayed towards Indigenous art worldwide. Morphy has argued that instead of apportioning blame it might be more productive and more interesting to examine the histories of inclusion. ${ }^{41}$ Given that the history of Aboriginal art in Australian art history has largely been one of exclusion and difference, a more successful model for an 'inclusionist' narrative might best be sought in another discipline. 


\section{Art history and anthropology}

Aboriginal art has been the focus of some important anthropological studies of Indigenous peoples-Mountford (1958, 1961), 42 Berndt (1971), Munn (1973), Morphy (1991), Taylor (1996) and Watson (2003) among them-even though it has been argued that 'art' objects have received little attention from anthropologists for much of the twentieth century. The reason, explains Morphy, is due partly to problems with the definition of art - the applicability of the concept cross-culturally - and due partly to neglect of material culture by anthropologists. ${ }^{43}$

Morphy categorises the history of approaches to the anthropology of art into three main types: first, typological sequencing linked to diffusionist or evolutionary paradigms; second, the explanation of form in relation to aesthetic effect; and third, stylistic analysis associated with culture, areas, tribes or schools. The last two of these methodological types have strong links to practices in art history, yet Morphy argues that 'the study of non-European art became constrained by the terminology and interests of the European and Euro-American art history of the time' ${ }^{44}$ This seems antithetical to the view that for much of the twentieth century anthropological descriptions of Aboriginal art contributed to the delayed inclusion of Aboriginal art in the art gallery. ${ }^{45}$ Clearly, Aboriginal art has been in a double bind for most of the twentieth century: not sufficiently 'fine' to be art and not sufficiently 'authentic' to be culture. Thus, it was effectively marginalised by both disciplines.

In his recent book Becoming Art (2008), Morphy suggests a more art-historical anthropology might address the neglect of Aboriginal art but is unconvinced that art history, as it stands, is a cross-cultural category. ${ }^{46}$ Even if one disagrees with Morphy on this point, the question remains: are two heads better than one? According to Robert Layton, anthropology brings many advantages to the study of art:

[A]nthropological studies of art provide useful antidotes to a number of tendencies in art-historical analysis. They challenge models of changes in style that regard naturalistic representation as the pinnacle of achievement; the tendency to map artistic culture areas without reference to the social functions of art; and the focus on artists or schools of artists in isolation from their place in a wider community. ${ }^{47}$

A cynical art historian might respond by suggesting that the discipline of art history, just like the rest of the humanities, has been mounting its own internal critique of these issues for quite some time. ${ }^{48}$ Whether or not these reassessments of art-historical method have been brought about as a result of the influence of anthropology is a matter of some speculation. The same cynical art historian might be similarly annoyed by Morphy's many references to 'the narrowness' 
of the definition of art in the Western category of fine art. ${ }^{49}$ It is important to be clear: artists do not have a particularly narrow definition of art; indeed, Tristan Tzara, Marcel Duchamp and Joseph Beuys demonstrate that. It is more that art has been a culturally constructed category and that these cultural boundaries are frequently traversed by artists but re-enforced by institutional structures such as museums and galleries and enshrined in a particular teleological art-historical narrative.

There are two important points to make in relation to this. One is that there are several different histories operating at once and not all 'arts' - for want of a better term - find equivalence in the same time frame; second is that the object of anthropological and art-historical studies differs in fundamental ways. The question of most importance for anthropology seems to be: how can the study of art contribute to an understanding of human cultures? Art history has different aims. At its most basic, 'the goal of art history is first to place the work of art in history and then assess it in light of its unique position'. ${ }^{50}$ Art history is also connected to related fields, such as criticism and connoisseurship, which require judgments of value and taste. Although the contents of, and the process of establishing, a canon of fine art has been under attack for some time, the art market, public museums and galleries still rely largely on this notion to establish their assessment criteria.

Donald Preziosi has emphasised the strong connection that exists between writing about art objects and the organising principles of the museum, at one stage referring to art history as museography. ${ }^{51}$ He has also observed that in the past quarter-century, various claims have been made about 'the need to rethink the "object" of art history, and the "profound contradiction" embodied by a "history of style...[as] the attempt to establish a narrative or causal chain within the assumed autonomy of art"', 52 Claire Farago has also pointed out that

the history of the classification of the arts and categories for judging artistic excellence deserves to be studied from a point of view broad enough to take into account the extensive migration of visual culture long before [European] global contact was initiated at the end of the fifteenth century. ${ }^{53}$

The history of art has always been global; however, certain narratives have dominated that reinforce particular paradigms at the expense of others.

Thus, it is important to reframe the question 'What is art?' Preziosi draws our attention to the philosopher Nelson Goodman, who states:

Part of the trouble lies in asking the wrong question-in failing to recognize that a thing may function as a work of art at some times and not at others...the real question is not 'What objects are (permanently) works of art?' but 'When is an object a work of art?' ${ }^{54}$ 
I have risked opening up a whole other pathway by introducing the topic of defining art (temporal or otherwise). Everyone who has an opinion on this topic, it seems, also has their own definition emphasising the aesthetic to a greater or lesser degree. I am not so much interested in charting the shifting status of objects or evaluating loose or tight definitions of art. Instead, my purpose is to critique the existing writing on Aboriginal art and to explore the limits and possibilities of an art history that does something for Aboriginal art. ${ }^{55}$

Should the category 'Aboriginal art' be understood more like a period style, especially in the way in which it is defined in traditional art history? Certainly, particular understandings of what is meant by the term 'Aboriginal art' appear to belong to particular historical epochs, although these are not defined according to style or iconography, which might befit a more traditional art history. ${ }^{56}$ This means that it is in the writing about the art rather than the art itself that we might find the location of the art's definition. An obvious limitation with this approach is that it reveals nothing about the thing in itself or what it is or does for people other than those writing about it. In a field as complex and sparsely researched as this, however, the introduction of such a critical framework must be an important first step. ${ }^{57}$

\section{Legacies of primitivism}

I believe that one important reason why it is taking so long for Indigenous art to be studied in any detail by present-day art historians is because many are still grappling with a way to deal with the category of 'primitive art'. 58 Sometimes confusion arises because the different meanings of the term 'primitive', as it is used in art history, become intertwined. There are at least three distinct meanings. First, as a largely archaic term, 'primitive' was used to refer to peoples outside the 'great centres of civilisation', reflecting the mistaken belief that some cultures were less advanced than others. Second, the term applies to the early phases within the historical development of painting or sculpture specifically in European countries, such as pre-Renaissance Italian art. Third, 'primitive' is a term used to describe artists with no formal training or whose works are highly idiosyncratic in a way that is outside the academic, traditional or even avant-garde manner. ${ }^{59}$ While some contemporary Indigenous artists' work could be described as primitive in that they work outside existing traditions (for example, H. J. Wedge or Ian Abdulla), the term is not used because of its negative connotations and for fear of reprisal.

Aboriginal art as primitive art has featured in many anthropological anthologies - Carol Jopling's Art and Aesthetics in Primitive Societies (1971) and Anthony Forge's Primitive Art and Society (1973) being just two examples. Earlier, Raymond Firth used 'Aboriginal art' as indicative of 'simple art' in his chapter, 'The social framework of primitive art', in the influential Elements of Social 
Organisation (1951). Despite the growing awareness throughout the twentieth century that the term 'primitive art' was increasingly inappropriate, it continued to be used. According to the Oxford Dictionary of Art, this was because 'agreement as to an alternative nomenclature was not reached' ${ }^{60}$ When current dictionaries define 'primitive' as 'early, ancient, old-fashioned, simple, rude', the term continues to cause offence.

Seeking an alternative, such as 'cultural art', 61 'world art' or 'ethnic art' while keeping the concept intact does nothing to address the issue. The Australian art historians Ian Burn and Ann Stephen clearly explain the negative aspects of the term primitive and its underlying meaning:

The primitive is a particular ideological construct in Western culture, a classification within an evolutionary view which locks non-European indigenous people like the Australian Aborigines into an earlier stage of human development and denies their art the possibility of being a mature, complex and contemporary expression. ${ }^{62}$

It is not possible completely to divorce these negative connotations of the past from any present-day use of the term. Similarly, substituting another term leaves the initial impetus unexamined. An alternative strategy would be to openly recognise the socio-political purpose and effects that such characterisations reflect and to be aware how words carry with them traces of past meanings. ${ }^{63}$ In order to gain a greater understanding of why the construct 'primitive' has remained a powerful categorical impulse in Western descriptions of 'non-Western' art, it is necessary to delve a little deeper into the beliefs that underpin it.

As a term, primitivism is difficult to define. Robert Goldwater writes in his highly influential study Primitivism in Modern Art ([1938], 1986) that '[p]rimitivism is not the name for a particular period or school in the history of painting, and consequently no description of a limited set of objective characteristics which will define it can be given'. ${ }^{64}$ Arthur Lovejoy and others, however, have been able to trace the concept back to antiquity. In A Documentary History of Primitivism and Related Ideas (1935), they argue that the concept of primitivism stemmed from two distinct tendencies in human thought; these have become confused and need to be separated. Lovejoy has named these tendencies 'chronological primitivism' and 'cultural primitivism'.

Chronological primitivism is concerned primarily with 'the temporal distribution of good, or value, in the history of mankind' and in determining when 'the best state of the world in general is supposed to occur'. ${ }^{65}$ Since chronological-primitivist beliefs situate the best of mankind in the past, they contrast with 'ideas of progress', as this phrase has come to be understood in the past two centuries. Cultural primitivism, on the other hand, is 'the discontent 
of the civilized with civilisation, or with some conspicuous and characteristic feature of it $^{66}$ and is concerned with a desire for a more simple, less-refined existence. As Lovejoy explains:

[T] he cultural primitivist's model of human excellence and happiness is sought in the present, in the mode of life of existing primitive, or so-called 'savage' peoples...the preacher of primitivism commends them as examples to be followed, or exhibits them as more fortunate branches of our species whose state is to be envied. ${ }^{67}$

I imagine that a version of cultural primitivism might be what Roger Benjamin is referring to when he uses the phrase 'the fetish for early Papunya boards' ${ }^{68}$ It is, however, the idea of progress that informs art history's 'teleological quest' and chronological primitivism that explains the placement of Aboriginal rock art in the opening chapter of three separate publications: William Moore's The Story of Australian Art (1934), James Gleeson's Australian Painters: Colonial 1788-1880, Impressionists 1881-1930, Modern 1931-1970 (1971) and, most recently, John McDonald's Art of Australia. Volume 1: Exploration to Federation (2008). All of these works position Indigenous Australian rock art at the beginning of their version of art in Australia and never mention it again. ${ }^{69}$ In essence, this variation on the inclusionist paradigm for writing Aboriginal/Australian art history slots Aboriginal art in where it appears to fit chronologically. There are several problems with this approach, not the least of which is that it supports a dangerous and misleading evolutionary paradigm, which continues to label Indigenous people as having 'a stone age culture'. 70

Chronological accounts of Western art have tended to position rock art in Europe at their origin. It does not make sense, then, to position Aboriginal rock art as the origin of non-Indigenous Australian art. Perhaps a more logical way in which to sequence rock art in the history of Australian art is by positioning it in relation to the point at which it was 'discovered' by non-Indigenous people. As problematic as this seems, it is still more honest than inserting it at the very beginning of an account of a tradition to which it bears little or no resemblance. There are a number of prominent contemporary critiques of primitivism, including works by James Clifford (1980), Sally Price (1989), Shelly Errington (1998), Thomas McEvilley (1992) and Mariana Torgovnick (1990). None of these critiques deals with the specific treatment (or lack thereof) of Indigenous art in Australia. Ironically, while Australian Aboriginal art continues to be marginalised in publications on Australian art, it is also marginalised in these critiques of primitivism and other publications on primitive art. ${ }^{71}$

\section{New art histories}

New art history has been defined as 'a capacious and convenient title that sums up the impact of feminist, marxist, structuralist, psychoanalytic, and 
socio-political ideas on a discipline notorious for its conservative taste in art and its orthodoxy in research'. ${ }^{72}$ It is often seen in opposition to traditional art history, which is defined as being 'about style, attributions, dating, authenticity, rarity, reconstruction, the detection of forgery, the rediscovery of forgotten artists and the meanings of pictures' ${ }^{73}$ The possibility of defining 'traditional' art history has, however, been put under a cloud, with some authors arguing that 'new art history' is an extension to the capacity of art history to apply critical methods to its own practices. ${ }^{74}$ If such a thing as new art history exists, can it aid in refining the methodology of an Aboriginal art history?

The main advantages of new art history appear to be in expanding the definition of art - the range of objects, media and issues - and also in the realm of critique. As film studies lecturer and feminist author A. L. Rees and Frances Borzello explain:

The new art historians question, giving not only art but the society which enshrines it a long, hard look. They question the status of art, and the most automatic assumption that art means paintings and sculptures in certain styles. They ask how such objects and not others came to be called 'art' in the first place, and why they alone are worthy of study. $^{75}$

This approach concentrates on the critique of extant orthodox histories of art, revealing how many of these histories are blind to their class, gender and racial biases. It also concerns itself with theory and the social conditions under which art is produced. But what if there is no received history to critique? Once the injustice of the omission has been made evident, how do we proceed? While it is possible to critique the social conditions of the reception of 'Aboriginal art', as demonstrated through the literature of the day, how can one critique the 'traditional' history of Aboriginal art if it is not on record? Certain deconstructionist techniques and gender, race and class theory have been useful in causing a revision of practices in humanities disciplines, but these 'tools' should not obscure the initial need to acknowledge a history of Aboriginal art. The material basis for 'new art history' resided in its development in several prominent teaching institutions in the United Kingdom: Leeds University, Middlesex Polytechinque and the so-called 'plate-glass universities' of East Anglia, Essex and Sussex. ${ }^{76}$ A similar expansion across the United States produced the 'inter-discipline' visual studies, also known as visual culture. One of the main protagonists of the push to include visual studies in the curriculum of universities, W. J. T. Mitchell, has suggested that 'aesthetics is an eighteenth-century discipline, art history a nineteenth-century one, and visual studies that of the twenty-first' ${ }^{77}$ In summarising the main positions of 'visual culture', Mitchell presents the following five 'moments': 
1. Visual culture should be mindful of the different disciplinary histories that have converged in it...2. Visual culture must resist the temptation to the sort of easy pluralism that would deny any general force to its central concept...vision is a cultural concept...3. Visual culture must address the relation of vision and the other senses...4. One of the principal objectives of visual culture is the de-reification of its theoretical object, human vision...5...it must be grounded not just in the interpretation of images, but also in the description of the social field of the gaze, the construction of subjectivity, identity, desire, memory, and imagination. 78

Mitchell's 'manifesto' of visual culture offers the potential for inclusion, expansion, re-evaluation and critique of the 'old' discipline of art history. Not everyone agrees that this is the 'right' way to go. Bernard Smith has argued that the discipline of art history already possesses the tools and techniques necessary to deal with the expanding world of visual culture. He states that 'art history needs to be more alert to the challenges that come from the empirical sciences than from those that proceed from fashionable philosophers who dabble in art history and from current ideologies' ${ }^{79}$ He outlines the main components of art history as identification, classification, evaluation and interpretation and devotes much effort to the defence of the existing scholarly rigours of the discipline. In her response, art critic and visual culture lecturer Anne Marsh has suggested that expanding the disciplinary boundaries of art history is an enriching process; inclusion acts to enliven the field. ${ }^{80}$ Importantly, she also emphasises that the main threat to art history comes from the economic rationalist agenda currently dominating decision making in Australian universities.

While I agree with Marsh about the current state of play with art history departments having to justify their place economically within Australian universities, Smith is right to defend the need for proper art-historical scholarship in Australia. This need is particularly acute in relation to the study of Aboriginal art, regardless of the ethnicity of the researcher.

In conclusion, while the debates between 'old' and 'new' art history and the introduction of studies of visual culture might contribute to an understanding of the shortcomings and potentialities of the field, they do not constitute an adequate platform from which it is possible to delve into the past while maintaining a perspective firmly focused on the future potential of writing about Aboriginal art. This platform can be established only once agreements have been reached between researchers and the subjects of the research. An open dialogue must take place concerning the aims and objectives, needs and wants of art history and those involved at all levels of the production, circulation, valuation and collection of Indigenous art. Coming to a shared understanding of the purpose of art history is vital for establishing honest relations between all parties. The 
best way to move forward is to find these points of agreement, which in turn have the potential to engender mutual respect.

\section{Author's note}

I would like to thank the following people for their generous feedback on this work: Dr Kylie Message, Professor Howard Morphy, Pip Deveson, Dr Rossella Ragazzi, Alison French, Anna Edmundson and the anonymous peer reviewers. This paper is a rewritten version of Chapter 1 of Writing on 'Aboriginal art' 1802-1929: a critical and cultural analysis of the construction of a category, Unpublished PhD thesis (2005). It also includes two paragraphs from a previously published review of The New McCulloch's Encyclopaedia of Australian Art for the Australian Book Review (no. 296, November 2007, pp. 20-1).

\section{ENDNOTES}

1 McGrath, Ann and Markus, Andrew 1987, 'European views of Aborigines', in D. H. Borchardt (ed.), Australians: A guide to sources, Fairfax, Syme and Weldon Associates, Sydney, p. 117.

2 From the visual equivalences drawn between late European and American modernists and Western Desert acrylics painters to the placement side by side of 'views' of Groote Eylandt, curators and critics are searching for different ways of drawing equivalences between Aboriginal and non-Aboriginal art. Some interesting conceptual and aesthetic approaches have been tried in the inaugural temporary exhibition at the National Portrait Gallery, Open Air: Portraits in the landscape, and a temporary hanging of the permanent collection of the Art Gallery of Western Australia by Acting Director, Gary Dufour, in September 2008.

3 Langton, Marcia 1993, 'Well, I Heard it on the Radio and I Saw it on the Television, Australian Film Commission, Woolloomooloo, New South Wales, pp. 23-8.

4 Benjamin, Roger 2000, 'The brush with words: criticism and Aboriginal art', in Sylvia Kleinert and Margo Neale (eds), Oxford Companion to Aboriginal Art and Culture, Oxford University Press, Melbourne, pp. 466-70. See also Benjamin, Roger (ed.) 2009, Icons of the Desert: Early Aboriginal paintings from Papunya, Distributed for the Herbert F. Johnson Museum of Art, Cornell University Press.

5 Rothwell, Nicolas 2009, 'From the desert, artists came', The Australian, 13 February, $<$ www.theaustralian.news.com.au/story/0,,25046305-16947,00.html>

6 Ibid.

7 Michaels, Eric 1988, 'Bad Aboriginal art', Art and Text, vol. 28, p. 73. See also Acker, Tim 2008, 'Aboriginal art: it's a complicated thing', Artlink, vol. 28, no. 3, pp. 64-8.

8 See Morphy, Howard 2008, Becoming Art: Exploring cross-cultural categories, University of New South Wales Press, Sydney.

9 See Jansen, Charles 1986, Studying Art History, Prentice-Hall, Englewood Cliffs, NJ. According to Jansen (p. 44), art history is deemed more objective and has an 'explanatory power', which differs from art criticism, which 'consists of opinions processed into judgments of quality'. Anne D' Alleva notes that 'art criticism is the practice of evaluating art for its aesthetic and cultural worth, rather than using it to tell history'. She also notes that writers such as Pliny the Elder and Giorgio Vasari mixed art history with art criticism but they became separate disciplines in the eighteenth century. See D'Alleva, Anne 2006, How to Write Art History, Laurence King Publishing, London. It is also worth noting that in Australia the disciplines have never been that distinct. Robert Hughes was art critic for The Observer about the same time as he wrote Art in Australia and Bernard Smith was art critic for the Age for the three years leading up to his publication of Australian Painting - still one of the foundational texts of Australian art history.

10 Langton, 'Well, I Heard it on the Radio and I Saw it on the Television', p. 24.

${ }^{11}$ See <www.naa.gov.au/about-us/research-grants/frederick-watson/former-fellows/deveson-2006.aspx>

12 Langton, 'Well, I Heard it on the Radio and I Saw it on the Television', p. 27.

13 Ibid., p. 28. 
14 Roskill, Mark 1976, What is Art History?, Thames and Hudson, London, p. 14.

15 Johnson, William McAllister 1988, Art History: Its use and abuse, University of Toronto Press, Toronto, p. 272.

16 See Soussloff, Catherine 1997, The Absolute Artist: The historiography of a concept, University of Minnesota Press, Minnesota.

17 See Morphy, Howard 1995, 'Aboriginal art in a global context', in Daniel Miller (ed.), Worlds Apart: Modernity through the prism of the local, Routledge, London and New York, pp. 211-39.

18 Some examples of these are the excellent catalogue Papunya Tula: Genesis and genius (2000), which outlines the birth of what some describe as the most revolutionary art movement in Australia; the encyclopedic reference work The Oxford Companion to Aboriginal Art and Culture (2000), which combines solicited essays by a range of Indigenous and non-Indigenous academics and artists with alphabetically indexed entries on important topics and people; and the classic introductory survey Aboriginal Art by Wally Caruana (1993, revised 2003), part of the World of Art series by Thames and Hudson.

19 Morphy, Howard 1998, Aboriginal Art, Phaidon Press Limited, London, p. 4.

20 Grishin, Sasha 2008, 'A new history of Australian art: dialectic between Indigenous and non-Indigenous art', International Journal of the Humanities, vol. 6, no. 7, pp. 59-65.

21 Ibid., p. 59.

22 Smith, Bernard 2005, 'On writing art history in Australia', Thesis Eleven, no. 82, p. 11.

23 Morphy, Aboriginal Art, p. 420.

24 Sayers, Andrew 2001, Oxford History of Art: Australian art, Oxford University Press, Hong Kong, p. 2.

25 Ibid., p. 1.

26 Ibid., p. 1.

27 Ibid., p. 1.

28 Ibid., p. 2.

29 Ibid., pp. 4-5.

30 Ibid., p. 6. Considering the amount of territory he covers, Sayers mentions 'Aboriginal art' in a surprising number of places throughout the work. Sayers begins with an account of the early reception of rock art, Baldwin Spencer's collections and the popularity of some forms of 'Aboriginal art' at the turn of the nineteenth century. He devotes an entire section, between post-object art and 'the provincialism problem' to 'contemporary Aboriginal art' - meaning acrylic painting of the Western Desert from 1971 onwards.

31 Ibid., p. 2.

32 Allen, Christopher 1997, Art in Australia: From colonization to postmodernism, Thames and Hudson, London, p. 106.

33 Ibid., p. 214.

34 Langton, Marcia 2000, 'Homeland: sacred visions and the settler state', Artlink, vol. 20, no.1, pp. 11-16.

35 Allen, Art in Australia, p. 215.

36 Ibid., p. 215.

37 Sayers, Oxford History of Art, p. 2.

38 Ibid., p. 6.

39 McCulloch, Susan 2007, Excerpt from interview transcript, Sunday Arts, ABC TV, <www.abc.net.au/tv/sundayarts/txt/s1786884.htm>, reproduced in Lowish, Susan 2007, ‘Too many Tjakamarras?', Australian Book Review, no. 296, November, pp. 20-1.

40 Oguibe, Olu 1993, 'In the "heart of darkness"', Third Text, no. 23, p. 3.

41 Morphy, Howard 2001, 'Seeing Aboriginal art in the gallery', Humanities Research, vol. 8, no.1, p. 37.

42 The inclusion of Mountford in this list might not sit well with some anthropologists, but he is an important figure in the promotion of Aboriginal art as a field of anthropological inquiry.

43 Differences between European and American schools of anthropology aside, Morphy argues that 'the source of the neglect of art and material culture can be traced to the end of the nineteenth century and the beginning of the twentieth, and is associated with the rejection of the evolutionary paradigm'. 
Morphy, Howard 1994, 'The anthropology of art', in Tim Ingold (ed.), Companion Encyclopaedia of Anthropology, Routledge, London and New York, p. 656.

44 Morphy, 'The anthropology of art', p. 657.

45 Stewart, June 1974, Bibliographical Essay on Art Historical Studies in Australia Since 1958, Griffin Press, Adelaide, p. 8.

46 Morphy, Becoming Art, p. 145.

47 Layton, Robert 1996, 'Anthropology and art', in Jane Turner (ed.), The Dictionary of Art, vol. 2, Grove for Macmillan, New York, p. 138.

48 See especially Preziosi, Donald 1989, Rethinking Art History: Meditations on a coy science, Yale University Press, New Haven and London.

49 See especially Morphy, Becoming Art, pp. 18-20.

50 Kleinbauer, W. Eugene and Slavens, Thomas P. 1982, Research Guide to the History of Western Art, American Library Association, Chicago, p. 3.

51 Preziosi, Donald (ed.) 1998, The Art of Art History: A critical anthology, Oxford University Press, Oxford and New York, p. 507.

52 Preziosi, Rethinking Art History, p. 2.

53 Farago, Claire 1995, 'Reframing the Renaissance', in Claire Farago (ed.), Reframing the Renaissance: Visual culture in Europe and Latin America 1450-1650, Yale University Press, New Haven and London, p. 1.

54 Preziosi, referencing Goodman, in Rethinking Art History, pp. 190-1.

55 It should be noted that by focusing on written works that already use the term 'Aboriginal art' the question is not 'are they art?' but instead becomes one of 'in what sense are they art?'

56 Wölfflin, Heinrich [1932] 1950, Principles of Art History: The problem of the development of style of later art, G. Bell and Sons, London.

57 Preziosi has stated of art history in general: 'its future survival as a discipline will be read in its ability to understand its own complex and contradictory history.' Preziosi, Rethinking Art History, p. 52 .

58 See, for example, the exchange that took place between Bernard Smith and Donald Brook in the pages of Meanjin (1987-88). See also Smith's distinction between 'art in the special sense' and 'art in the general sense' in Smith, Bernard 1998, Modernism's History: A study in twentieth-century art and ideas, University of New South Wales Press, Sydney; and Smith, Bernard 2006, 'Creators and catalysts: the modernisation of Australian Indigenous art', ACH: The Journal of the History of Culture in Australia. Special Issue: Antipodean Modern, vol. 25, pp. 11-25.

59 Osbourne, Harold (ed.) 1970, Oxford Companion to Art, Oxford University Press, Oxford, p. 925. 60 Ibid., p. 924.

61 See Labbé, Armard J. 1992, Images of Power: Masterworks of the Bowers Museum of Cultural Art, Culture Arts Press, Santa Ana, California.

62 Burn, Ian and Stephen, Ann 1992, 'Namatjira's white mask: a partial interpretation', in Jane Hardy, J. V. S. Megaw and M. Ruth Megaw (eds), The Heritage of Namatjira, William Heinemann, Melbourne, p. 252.

63 For more on the theoretical basis of this idea, see Bakhtin, Mikhail [1975] 1981, The Dialogic Imagination, Edited by Michael Holquist, University of Texas Press, Austin, Texas.

64 Goldwater, Robert [1938] 1986, Primitivism in Modern Art, Enlarged edition, The Belknap Press of Harvard University Press, Cambridge, Mass., and London, p. xxiv. Note: when first published, in 1938, the title appeared as Primitivism in Modern Painting.

65 Lovejoy, Arthur et al. 1935, A Documentary History of Primitivism and Related Ideas, Johns Hopkins Press, Baltimore, p. 1.

66 Ibid., p. 7.

67 Ibid., p. 8.

68 Benjamin, Roger 2009, 'The fetish for Papunya boards', in Roger Benjamin (ed.), Icons of the Desert: Early Aboriginal paintings from Papunya, pp. 21-50.

69 This is particularly strange in McDonald's work, as a major and beautiful illustration in the first chapter is a two-page spread of the main gallery in the Nourlangie Rock area of Kakadu National Park, Northern Territory. According to George Chaoulopkka, this particular frieze was painted in 1964 by 
Najombolmi ('Barramundi Charlie'). Chaoulopkka, George 1982, Burrunguy Nourlangie Rock, Northart, Darwin.

70 Senator Nigel Scullion, Senator for Northern Territory, Deputy Leader of The Nationals, Member of the Country Liberal Party, said in his maiden speech to Parliament, '[I]f you ever get a phone call from somebody who claims to have the answer to the challenges facing indigenous Australia, just hang up...I am sure that the social debris from the collision between a Stone Age culture and modern times is not going to be cleaned up through implementing just one or two ideas'

(<http://www.aph.gov.au/senate/senators/homepages/first_speech/sfs-00AOM.htm>).

71 See Phelps, Steven 1975, Art and Artefacts of the Pacific, Africa and the Americas, Huchinson and Co., London. This large tome contains only six pages on Australia, utilising Spencer and Gillen (1899) and Basedow (1925) as references. Similarly, Pericot-Garcia, Luis et al. (1969, Prehistoric and Primitive Art, Thames and Hudson, London) contains a mere five paragraphs based on the work of D. S. Davidson.

72 Rees, A. L. and Borzello, Frances (eds) 1986, The New Art History, Camden Press, London, p. 2.

73 Ibid., p. 2, summarising the main tenets of Roskill, What is Art History?.

74 See Bann, Stephen 1986, 'How revolutionary is the new art history?', in Rees and Borzello, The New Art History, pp. 19-13; and Preziosi, Rethinking Art History, pp. 19-31.

75 Rees and Borzello, The New Art History, p. 4.

76 Ibid., p. 6.

77 Quoted in Holly, Michael Ann and Moxey, Keith 2002, Art History, Aesthetics, Visual Studies, Sterling and Francine Clark Art Institute, Williamstown, Mass., p. ix.

78 Ibid., pp. 544-5.

79 Smith, Bernard 2000, 'In defence of art history', Art Monthly Australia, no. 130, p. 6.

80 Marsh, Anne 2000, 'The future of art history: the discipline in an expanded field', Art Monthly Australia, no. 133, p. 10. 